\title{
WARU LEAF (Hibiscus tiliaceus) AS SAPONIN SOURCE ON In vitro RUMINAL FERMENTATION CHARACTERISTIC
}

\author{
L. Istiqomah ${ }^{1}$, H. Herdian ${ }^{1}$, A. Febrisantosa ${ }^{1}$ and D. Putra ${ }^{2}$ \\ ${ }^{1}$ Research Unit for Development of Chemical Engineering Processes, \\ Indonesian Institute of Sciences (LIPI), \\ Jl. Jogja - Wonosari Km. 31, Gading, Playen, Gunungkidul, Yogyakarta 55861-Indonesia \\ ${ }^{2}$ Faculty of Mathematics and Natural Science, Sebelas Maret University \\ Jl. Ir. Sutami 36 A Surakarta 57126 - Indonesia \\ CorrespondingE-mail: ps_uty@yahoo.com
}

Received December 10, 2010; Accepted February 16, 2011

\begin{abstract}
The effect of waru leaf (Hibiscus tiliaceus) supplementation as saponin source on ruminal fermentation characteristics were studied using in vitro gas production techniques. Rumen fluid was taken from fistulated Ongole crossbreed cattle. The treatments consisted of control treatments (Napier grass with monensin and Napier grass without waru leaf $(0 \%$ saponin level) and waru leaf supplementation treatments as much as $11,22,33$, and $44 \mathrm{mg}$ of feed (in dry matter basis) or equal to 5 , 10, 15, and 20\% saponin level added to feed substrate of Napier grass (Pennisetum purpureum). The result showed that protozoa numbers and total gas production were significantly reduced $(\mathrm{P}<0.05)$ in line with the increasing of saponin level compared to $0 \%$ saponin level, while $\mathrm{NH}_{3}$, VFA concentration and $\mathrm{pH}$ after $48 \mathrm{~h}$ fermentation were not affected by the treatment. VFA concentration increased by waru leaf up to $10 \%$ saponin level then decreased at level 15 and $20 \%$. Ratio of acetate to propionate (A/P) and non glucogenic ratio (NGR) decreased at 5, 10, and 15\% saponin level, but increased at level $20 \%$. It could be concluded that waru leaf supplementation at $10 \%$ saponin level of feed was the optimum level which gave positive effect on rumen feed fermentation.
\end{abstract}

Keywords: In vitro, ruminal fermentation, saponin, waru leaf (H. tiliaceus)

\section{INTRODUCTION}

The main products of fermentation of feed organic matter in ruminant were volatile fatty acid (VFA), gases and microbial biomass (mainly protein) (Alexander et al., 2008). The protein source for ruminant, additional to microbial protein also came from feed protein escaped from rumen degradation. Existence of protozoa in the rumen has an effect on flow of protein into duodenum. Unlike bacteria, protozoa has no urea and could not use ammonia as a nitrogen source. They ingested bacterial and dietary proteins, and excreted as much as $50 \%$ of ingested nitrogen in the form of amino acids and ammonia (Jouany, 1991). Several studies showed free fatty acids reduced protozoa numbers, as well, and low $\mathrm{pH}$ may cause defaunation (Owens et al., 1998). Removing ciliate protozoa from rumen may prevent recycling of $\mathrm{N}$ between bacteria and protozoa, and thereby increased the efficiency of $\mathrm{N}$ metabolism in rumen and stimulated flow of microbial protein into small intestine (Teferedegne, 2000). Moreover protozoa also well known associated with methane emission from enteric fermentation trough interspecies commensalisms with methanogenic archaea. Seventy percent of total methanogenesis was associated with the protozoa (Dore and Gouet, 1991).

Several strategies were suggested to modify rumen fermentation to make it more efficient in fiber digestion or to have less protein degradation or less intra ruminal nitrogen turn over and hence have more outflow of protein to duodenum. Many plants produced secondary metabolites, a group of chemicals that were not involved in the primary biochemical processes of plant growth and reproduction but were important to protect plants from insect predation or grazing by herbivores. Several thousand plant secondary metabolites had been reported such as saponins that had antimicrobial activity (Vincken et al., 2007). Saponins were glycosides of aglycone linked to 
one or more sugar chain that were generally considered as anti nutritional factors (Teferedegne, 2000). Saponin showed a toxic effect on rumen protozoa (Newbold et al., 1997). The toxicity of saponin to protozoa was obviously the result of their detergent effect on the cell membrane. The sensitivity of protozoa toward saponin was caused by their membrane sterol bind with saponin (Wina et al., 2005) which formed insoluble complexes and caused cell lysis (Francis et al., 2002).

Hibiscus tiliaceus leaf was a native tropical plant contains saponin that may be used as defaunating agent in ruminant. In some area these plants commonly being used as the alternative feed for ruminant, particularly on dry season, but the study of its effect was limited. Therefore the objective of this study was to evaluate the effect of Hibiscus tiliaceus leaf supplementation as saponin source on in vitro feed fermentation on rumen.

\section{MATERIALS AND METHODS}

\section{Plant Material, Chemical Composition, and Saponin Analysis}

Hibiscus tiliaceus leaf was grounded to pass a $1 \mathrm{~mm}$ screen and dried in oven at $55^{\circ} \mathrm{C}$ for $72 \mathrm{~h}$. Saponin analysis was done according to Makkar et al. (2007). The data of saponin concentration was used to calculate the amount of $H$. tiliaceus leaf that was added to substrate. Monensin $(2 \mathrm{mg})$ was used as positive control (G.200 ${ }^{\mathrm{C}}$ Monensin Sodium Elanco Animal Health Division). Dry matter (DM), crude protein (CP), and crude fiber (CF) were analyzed by AOAC method (1995).

\section{Incubation}

The effect of this plant supplementation on ruminal fermentation was examined by in vitro gas production following procedure described by Menke et al. (1979). Two ruminally fistulated Ongole crossbred cattle were used as rumen liquor donor. Animals were fed twice daily with a basal diet consisting of Napier grass and concentrate (70:30, on DM basis). Rumen fluid was taken using aspirator, and immediately transported in pre warmed vacuum flask $\left(39^{\circ} \mathrm{C}\right.$ water temperature) and filtered. H. tiliaceus leaf was applied in a series dosage appropriate to level of saponin $0,5,10,15$, and $20 \%$ of feed (in dry matter basis), replacing equivalent amount of Napier grass.

\section{Treatments and Statistical Analysis}

Experimental design of this study was Completely Randomized Design with six treatments descripted as follows:

1. P. purpureum $(200 \mathrm{mg})+H$. tiliaceus (level of saponin $0 \%$ of feed in DM basis)

2. P. purpureum $(200 \mathrm{mg})+H$. tiliaceus (level of saponin $5 \%$ of feed in DM basis)

3. P. purpureum $(200 \mathrm{mg})+H$. tiliaceus (level of saponin $10 \%$ of feed in DM basis)

4. P. purpureum $(200 \mathrm{mg})+H$. tiliaceus (level of saponin $15 \%$ of feed in DM basis)

5. P. purpureum $(200 \mathrm{mg})+H$. tiliaceus (level of saponin $20 \%$ of feed in DM basis)

6. P. purpureum $(200 \mathrm{mg})+$ Monensin $(2 \mathrm{mg})$

Effect of treatment was analyzed using the test of variance (ANOVA) and differences between treatments were analyzed using Duncan's Multiple Range Test (DMRT) (Gomez and Gomez, 1984).

\section{Measurement of Gas Production}

Gas production was measured by Menke and Steingass procedure (1988). Fermentation was conducted in glass size $100 \mathrm{~mL}$ syringe (Fortuna model, Poulten and Graft Gmbh Germany). A total of $200 \mathrm{mg}$ of Napier grass substrate and $H$. tiliaceus leaf were entered into the syringe and incubated for one night in an incubator at $39^{\circ} \mathrm{C}$. Then, along with $\mathrm{CO}_{2}$ flow, a mixture of rumen fluid was added by a medium mixture of $30 \mathrm{~mL}$ with a ratio of 1:2 into the syringe. All of the measurements were repeated three times. Incubation was then continued for $48 \mathrm{~h}$ at $39^{\circ} \mathrm{C}$. Gas production measurements were performed at $0,3,6,12,24,48 \mathrm{~h}$. After $48 \mathrm{~h}$ incubation gas was released, whereas rumen fluid contained in syringe samples taken for analysis of protozoa population, VFA, and $\mathrm{NH}_{3}$.

\section{Observed Variables}

Variables measured were protozoa numbers, gas production, VFA concentration, ammonia concentration, and $\mathrm{pH}$ rumen fluid. After $0,3,6$, 12,24 , and $48 \mathrm{~h}$ of incubation, gases were measured and syringe contents were transferred to centrifuge tubes and were centrifuged at $500 \mathrm{x} \mathrm{g}$ for $20 \mathrm{~min}$ at $4^{\circ} \mathrm{C}$. The $\mathrm{pH}$ of medium was determined using digital $\mathrm{pH}$ meter. The calculation of protozoa number was done using MFS solution composed of $20 \mathrm{~mL} \quad 35 \%$ formaldehyde solution, $0.12 \mathrm{~g}$ of methyl green, and $1.6 \mathrm{~g}$ of $\mathrm{NaCl}$ and hemocytometer according 
to Diaz et al. (1993). VFA measurements were carried out according to method of Santoso and Hariadi (2007) using Gas Chromatography (Shimadzu GC8). Measurement of microbial rumen fluid was done using the Lowry et al. (1951) method modificated by Waterborg (2002).

\section{RESULTS AND DISCUSSION}

Nutrient composition of Napier grass (Pennisetum purpureum) and waru leaf (Hibiscus tiliaceus) are presented in Table 1. Crude protein content in $P$. purpureum and $H$. tiliaceus were higher than the minimum concentration of $\mathrm{CP}$ (7\%) required for microbial activity (Crowder and Chheda, 1982). High protein content was good enough for cattle to protein needs. Crude fiber of $H$. tiliaceus leaf was lower than the Napier grass that was good to reduce methane gas production, while carbohydrate content of $H$. tiliaceus was high $(45.91 \%)$ that may available for livestock as source of energy. Saponin content of H. tiliaceus leaf in this study $(8.93 \mathrm{mg} / \mathrm{g} \mathrm{DM})$ was lower than the saponin content of Acacia mangium Willd (16.7 mg/g DM) (Santoso and Hariadi, 2007).

\section{Protozoa Number and Fermentation Product}

In this study the protozoa number in rumen fluid decreased significantly $(\mathrm{P}<0.05)$ by the $H$. tiliaceus leaf supplementation in line with the increasing of saponin level (Table 2). H. tiliaceus leaf supplementation at level $10 \%$ decreased the protozoa number as much as $43.08 \% \quad(9.25$ $\left.\times 10^{3} / \mathrm{mL}\right)$ than that of control $\left(16.25 \times 10^{3} / \mathrm{mL}\right)$. Supplementation of plant extracts containing saponins reduced the population of protozoa linearly with the increasing of saponin dose (Teferedegne et al., 1999). Wina et al. (2005) reported that saponin of methanol extract of Sapindus rarak decreased protozoa number and increased microbial protein synthesis as well as VFA in in vitro study. Saponin of tea was also reported decreased protozoa number on growing lamb (Mao et al., 2010).

Saponin could disrupt the development of protozoa by the bond between the saponin with sterols in protozoa cell membrane surface that may affect cell membrane permeability (Patra et al., 2006) and further may cause membrane rupture, cell lysis and death. The presence of cholesterol content in eukaryotic (including protozoa) cell membranes, but not in prokaryotic bacterial cell (Hussain and Cheeke, 1995), suggested a possible selective susceptibility of ruminal ciliate protozoa to saponins due to an affinity of saponin to cholesterol.

According to gas production data in Table 2, it was known that monensin and waru leaf $(H$. tiliaceus) depress gas production significantly $(\mathrm{P}<0.05)$ compared to controls. H. tiliaceus leaf supplementation as much as $5,10,15$, and $20 \%$ and the monensin addition on fermentation of Napier grass by rumen microbes in vitro decreased gas production $(\mathrm{P}<0.05)$ compared to control $(47.17 \mathrm{~mL}) . \quad H . \quad$ tiliaceus leaf supplementation at level $10 \%$ decreased the gas production as much as $11.02 \%(41.97 \mathrm{~mL})$ than control $(47.17 \mathrm{~mL})$, but there were no difference ( $\mathrm{P}>0.05$ ) among level 10 and $15 \%$ of $\mathrm{H}$. tiliaceus leaf supplementation. Monensin treatment as positive control produced the lowest gas production $(18.48 \mathrm{~mL})$, followed by level $20 \%$ of H. tiliaceus leaf supplementation $(38.47 \mathrm{~mL})$.

The reduction of gas production in this study was associated with the reducing protozoa number; when the protozoa number was less, then the gas production decreased. The gas production contained $\mathrm{CO}_{2}$ and $\mathrm{CH}_{4}$, which was caused by the fermentation of carbohydrates in the rumen and consisted of $32 \% \mathrm{CH}_{4}, 56 \% \mathrm{CO}_{2}$ and $3.5 \% \mathrm{O}_{2}$

Table 1. Nutrient Composition of P. purpureum and H. tiliaceus (\% Dy Matter)

\begin{tabular}{lcc}
\hline & P. purpureum & H. H. tiliaceus \\
\hline Crude protein (\%) & 11.50 & 17.08 \\
Ether extract (\%) & 3.20 & 3.45 \\
Crude fiber (\%) & 29.30 & 22.77 \\
Ash (\%) & 15.90 & 10.79 \\
Carbohydrate (\%) & 40.10 & 45.91 \\
Tannin (\%) & 7.55 & 8.93 \\
Saponin (mg/g) & 8.01 & 12.90 \\
\hline
\end{tabular}


Table 2. Protozoal Number and Fermentation Product at $48 \mathrm{~h}$ Incubation of Feed with Various Level of Supplementation of Hibiscus tiliaceus Leaf as Saponin Source and Monensin

\begin{tabular}{lcccccc}
\hline \multirow{2}{*}{ Observed Variables } & \multicolumn{5}{c}{ Level of H. tiliaceus Leaf Supplementation } & \\
\cline { 2 - 6 } & $0 \%$ & $5 \%$ & $10 \%$ & $15 \%$ & $20 \%$ & \\
\hline Protozoal number, $\mathrm{x} 10^{3} / \mathrm{mL}$ & $16.25^{\mathrm{d}}$ & $4.50^{\mathrm{c}}$ & $9.25^{\mathrm{b}}$ & $9.00^{\mathrm{b}}$ & $6.75^{\mathrm{a}}$ & $7.25^{\mathrm{a}}$ \\
Fermentation product & & & & & & \\
$\quad$ Gas production, $\mathrm{mL}$ & $47.17^{\mathrm{a}}$ & $44.29^{\mathrm{b}}$ & $41.97^{\mathrm{c}}$ & $40.43^{\mathrm{c}}$ & $38.47^{\mathrm{d}}$ & $18.48^{\mathrm{e}}$ \\
$\quad$ Total VFA, mM/L & $137.39^{\mathrm{abc}}$ & $152.93^{\mathrm{ab}}$ & $165.81^{\mathrm{a}}$ & $127.15^{\mathrm{bc}}$ & $129.54^{\mathrm{bc}}$ & $106.67^{\mathrm{c}}$ \\
VFA, mM/L & & & & & & \\
Acetic acid & $99.17^{\mathrm{abc}}$ & $109.38^{\mathrm{ab}}$ & $115.90^{\mathrm{a}}$ & $89.51^{\mathrm{bc}}$ & $90.37^{\mathrm{bc}}$ & $70.78^{\mathrm{c}}$ \\
Propionic acid & $25.89^{\mathrm{abc}}$ & $31.35^{\mathrm{ab}}$ & $35.01^{\mathrm{a}}$ & $27.35^{\mathrm{bc}}$ & $23.29^{\mathrm{bc}}$ & $25.68^{\mathrm{c}}$ \\
Butyric acid & $12.33^{\mathrm{abc}}$ & $12.20^{\mathrm{ab}}$ & $14.90^{\mathrm{a}}$ & $10.28^{\mathrm{bc}}$ & $15.87^{\mathrm{bc}}$ & $10.20^{\mathrm{c}}$ \\
A/P Ratio & 3.83 & 3.49 & 3.31 & 3.27 & 3.88 & 2.76 \\
$\quad$ NGR & 4.83 & 4.34 & 4.16 & 4.05 & 5.24 & - \\
\hline
\end{tabular}

Different superscript in the same row indicates significantly different $(\mathrm{p}<0.05)$

(Arora, 1989). The study results of Santoso and Hariadi (2007) using Acacia mangium in $P$. purpureum at levels 15,30 and $45 \%$ in $100 \%$ of the substrate indicated the volume of gas after 48 $h$ incubation decreased linearly with the increasing concentration of Acacia mangium, being $57,48.2$, and $37.5 \mathrm{~mL}$, respectively, that was lower than that of control treatment (64.7 $\mathrm{mL})$. Hu et al. (2005) reported in his study that tea saponin at $0,0.2,0.4 \mathrm{mg} / \mathrm{mL}$ has a defaunating effect on protozoa and gas production (93.0, 90.5 and $92.0 \mathrm{~mL}$ ).

The very high differences in gas production effect between the $H$. tiliaceus leaf with monensin supplementation was occurred because the $H$. tiliaceus leaf gave an effect on the decreasing of protozoa number, but it did not gave a significant difference on bacterial activity in rumen. Meanwhile, monensin as manipulator of rumen fermentation would reduce the population of protozoa, suppressed the populations of bacteria and methane production.

Total VFA production in this study ranged from 106.67 to $165.81 \mathrm{mM}$. VFA production was a sufficient condition for optimal rumen microbial protein synthesis, because VFA range required for rumen microbial growth was $80-160 \mathrm{mM}$ (Van Soest, 1994). Other studies stated that the range of VFA in the rumen was $60 \mathrm{mM}$ acetic acid, $20 \mathrm{mM}$ propionate and $10 \mathrm{mM}$ butyrate (Madigan et al., 2003). The increased VFA concentration in response to the increasing of saponin could be due to the reducing outflow from the reticulorumen, inhibition of VFA absorption by the ruminal ephitelium, or increasing of microbial VFA production. Supplementation of Sapindus saponaria fruits contained $120 \mathrm{~g}$ of saponin improved the ruminal VFA profile, microbial efficiency, and duodenal flow of microbial protein in sheep fed tropical grass-alone or grass-legume diet (Abreu et al., 2004).

In Table 3, H. tiliaceus leaf supplementation resulted the ratio of acetic to propionate $(\mathrm{A} / \mathrm{P})$ lower than the control. A/P ratio of control was 3.83 while the $\mathrm{A} / \mathrm{P}$ ratio of $H$. tiliaceus supplementation $5,10,15$, and $20 \%$ and monensin were $3.49,3.31,3.28,3.88$ and 2.76 respectively. It has been suggested that there is an increased proportion of propionate in the rumen compared to acetate. H. tiliaceus played a role in glucose metabolism affected production of propionate that was glucogenic. Rumen fermentation system that leads to the propionate also resulted in the value of non-glucogenic ratio (NGR) tends to decrease. Increased propionate which was glucogenic will reduce the value of NGR. NGR value in this study by $H$. tiliaceus supplementation 5,10 , and $15 \%$ (4.34, 4.16, and 4.05 , respectively) were lower than the control (4.83), while at level $20 \%$ of $H$. tiliaceus supplementation resulted greater $\mathrm{A} / \mathrm{P}$ ratio and NGR than control. 
Table 3. Ammonia Concentration and $\mathrm{pH}$ after $48 \mathrm{~h}$ Incubation of Feed with Various Level Supplementation $H$. tiliaceus Leaf as Saponin Source and Monensin

\begin{tabular}{lrrrrrr}
\hline \multirow{2}{*}{ Observed Variables } & \multicolumn{5}{c}{ Level of H. tiliaceus Leaf Supplementation } & \multirow{2}{*}{ Monensin } \\
\cline { 2 - 6 } & \multicolumn{1}{c}{$0 \%$} & \multicolumn{1}{c}{$5 \%$} & $10 \%$ & $15 \%$ & $20 \%$ & \\
\hline Ammonia $(\mathrm{mg} / 100 \mathrm{~mL})$ & 35.63 & 36.72 & 37.96 & 38.13 & 34.88 & 33.99 \\
$\mathrm{pH}$ & 7.06 & 7.07 & 7.05 & 7.03 & 7.11 & 7.15 \\
\hline
\end{tabular}

\section{Parameter of Fermentation}

Manipulation on rumen fermentation should be considered to maintain fermentation process and main function of rumen on fiber digestion. Ammonia concentration and $\mathrm{pH}$ value were two factors among other factors that influenced the rumen fermentation. In this study, the determination of ammonia concentration in rumen fluid was done using Raneff method (Chaney and Marbach, 1962). Table 3 showed that monensin treatment or $H$. tiliaceus leaf supplementation was not significantly different $(\mathrm{P}>0.05)$ compared to controls. The results also showed the tendency that $H$. tiliaceus leaf supplementation at level 5, 10 , and $15 \%$ increased ammonia concentration, while the supplementation of monensin and $H$. tiliaceus leaf supplementation at level $20 \%$ tend to decrease the concentration of $\mathrm{NH}_{3}$. Mao et al. (2010) reported that tea saponin decreased ammonia concentration and $\mathrm{pH}$ on growing lamb.

According to Madigan et al. (2003), the ammonia concentration in the rumen was balance between the production rate of $\mathrm{NH}_{3}$ from the food and the use of $\mathrm{NH}_{3}$ for microbial growth and endogenous compounds. Ammonia concentration obtained in this study varied at $30-42 \mathrm{mg} / 100 \mathrm{~mL}$. For maximum growth of rumen microbes, the concentration of $\mathrm{NH}_{3}$ needed is $8.5 \mathrm{mg} / 100 \mathrm{~mL}$ of rumen fluid (Arora, 1989). Role of $\mathrm{N}$-ammonia was very important as a raw material to form cells in the process of rumen microbial protein metabolism. In this study, rumen fluid ammonia values were relatively high. The high concentration of ammonia indicated the high value of easily degradable protein in these rations.

In this study, $\mathrm{pH}$ of rumen fluid was not influenced by $H$. tiliaceus $(\mathrm{P}>0.05)$ (Table 3$)$. It means that saponin content on $H$. tiliaceus did not interrupt the fermentation function on rumen. This study showed the $\mathrm{pH}$ ranged between 7.03-7.15. Deamination produced $\mathrm{NH}_{3}, \mathrm{CO}_{2}$, and VFA, while at the decarboxylation step to produce amines and $\mathrm{CO}_{2}$ due decarboxylase activity. Low $\mathrm{pH}$ caused the condition become acidic and lower rumen microbial population so the process of proteolysis would be inhibited and as a result of degradation of feed will go down (Madigan et al., 2003).

Nagaraja and Titgemeyert (2007) reported that ruminal $\mathrm{pH}$ generally was higher than 5.5 and often in the range from 5.8 to 6.5 in grain adapted cattle. Therefore it could be concluded that $\mathrm{pH}$ obtained in this study indicated the occurrence of cellulose fermentation process optimally. Ruminal $\mathrm{pH}$ was critical factor in normal and stable function of the rumen because of its profound effect on microbial populations and fermentation products, and on physiological function in the rumen, mainly on its motility and absorptive function.

\section{CONCLUSION}

Waru leaf (Hibiscus tiliaceus) supplementation at $10 \%$ saponin level of feed (in dry matter basis) was the optimum level because its ability to modify rumen fermentation characteristics which leads to the synthesis of propionate, reduced protozoa population and gas production, and there was no effect on the $\mathrm{NH}_{3}$ concentration, VFA concentration, and $\mathrm{pH}$ value. Waru leaf $(H$. tiliaceus) supplementation also increased the proportion of propionate which was the main energy source for beef cattle.

\section{REFERENCES}

Abreu, A., J.E. Carulla, C.E. Lascano, T.E. Diaz, M. Kreuzer and D.H. Hess. 2004. Effects of Sapindus saponaria fruits on ruminal fermentation and duodenal nitrogen flow of sheep fed a tropica grass diet with and without legume. J. Anim. Sci. 82: 1392-1400.

Alexander, G., B. Singh, A. Sahoo and T.K. Bhat. 2008. In vitro screening of plant extracts to enhance the efficiency of utilization of energy and nitrogen in ruminant diets. Anim. 
Feed Sci. Technol. 145:229-244.

AOAC. 1995. Official Methods of Analysis. $16^{\text {th }}$ ed. Association of Official Analytical Chemists, Arlington, VA, US.

Arora, S. P. 1989. Microbes Digestion in Ruminant. $2^{\text {nd }}$ ed. Gadjah Mada University Press: Yogyakarta.

Chaney, A.L. and E.P. Marbach. 1962. Modified reagents for determination of urea and ammonia. Clin. Chem. 8:130-132.

Crowder, L.V. and H.R. Chheda. 1982. Tropical Grassland Husbandry. Longman Group Limited, New York, USA.

Diaz, A., M. Avendano and A. Escobar. 1993. Evaluation of Sapindus saponaria as a defaunating agent and its effects on different rumen digestion parameters. Livest. Res. Rural Dev. 5:1-6.

Dore, J. and $\mathrm{Ph}$. Gouet. 1991. Microbial interaction in the rumen. In: Rumen Microbial Metabolism and Ruminant Digestion. Jouany ed. INRA Paris

Francis, G., Z. Kerem, H.P.S. Makkar and K. Becker. 2002. The biological action of saponins in animal systems: a review. Br. J. Nutr. 88:587-605.

Gomez, K.A. and A.A. Gomez. 1984. Statistical Procedures for Agricultural Research. $2^{\text {nd }}$ ed. An International Rice Research Institute Book. John Willey and Sons Inc. New York. Toronto.

Hu, Wei-lian, W. Yue-ming, L. Jian-xin, G. Yanqiu and Y. Jun-an. 2005. Tea saponins affect in vitro fermentation and methanogenesis in faunated and defaunated rumen fluid. Zhejiang Univ. SCI 6B(8):787-792.

Hussain I. and P.R. Cheeke. 1995. Effect of Yucca schidigera extract on rumen and blood profiles of steers fed concentrate- or roughage- based diets. Anim. Feed Sci. and Technol. 51:231-242.

Jouany, J.P. 1991. Defaunation of the rumen. In: Rumen Microbial Metabolism and Ruminant Digestion. Jouany ed. INRA Paris.

Lowry, O.H., N.J. Rosebrough, A.L. Farr and R.J. Randall. 1951. Protein measurement with the folin phenol reagent. J. Biol. Chem. 193:265275.

Madigan, M.T., J.M. Martinko and J. Parker. 2003. Brock Biology of Microorganisms. Southern Illinois University Carbondale. $10^{\text {th }}$ ed. Pearson Education, Inc.

Makkar, H.P.S., P. Sidduraju and K. Becker. 2007. Plant Secondary Metabolites. Humana Press.
Totowa. New Jersey.

Mao, H.L., J.K. Wang, Y.Y. Zhou and J.X. Liu. 2010. Effect of addition of tea saponins and soybean oil on methane production, fermentation and microbial population in the rumen of growing lambs. Livestock Sci. 129: 56-62.

Menke, K.H., L. Raab, A. Slewski, H. Steingass, D. Fritz and W. Schneider. 1979. The estimation of the digestibility and metabolisable energy content of ruminant feedingstuffs from the gas production when they are incubated with rumen liquor. J. Agric. Sci. 93:217-222.

Menke, K.H. and Steingass, H. 1988. Estimation of the energetic feed value obtained from chemical analysis and in vitro gas production using rumen fluid. Anim. Res. Dev. 28:7-55.

Nagaraja, T.G. and E.C. Titgemeyert. 2007. Ruminal acidosis in beef cattle: the current microbiological and nutritional outlook. J. Dairy. Sci. 90: 17-38.

Newbold, C.J., S.M. El Hassan, J. Wang, M.E. Ortega and R.J. Wallace. 1997. Influence of foliage from African multipurpose trees on activity of rumen protozoa and bacteria. Br. J. Nutr. 78: 237-249.

Owens, F.N., D.S. Secrits, W.J. Hill and D.R. Gill. 1998. Acidosis in cattle: a review. J. Anim. Sci. 76:275-286.

Patra, A.K., D.N. Kamra and N. Agarwal. 2006. Effect of plant extracts on in vitro methanogenesis, enzyme activities and fermentation of feed in rumen liquor of buffalo. Anim. Feed Sci. Technol. 128:276291.

Santoso, B. and B.T. Hariadi. 2007. Effect of supplementation of Acacia mangium Willd in Pennisetum purpureum on fermentation characteristic and methane production in vitro. Med. Pet. 30(2):106-113.

Teferedegne, B. 2000. New perspectives on the use of tropical plants to improve ruminant nutrition. Proceedings. Nutrition Society. 59:209-214.

Teferedegne, B., F. McIntosh, P. O. Osuji, A. Odenyo, R. J. Wallace and C. J. Newbold. 1999. Influence of foliage from different accessions of the sub-tropical leguminous tree, Sesbania sesban, on ruminal protozoa in Ethiopian and Scottish sheep. Anim. Feed Sci. Technol. 78:11-20.

Van Soest, P.J. 1994. Nutritional Ecology of The Ruminant. $2^{\text {nd }}$ ed. Comstock Publishing 
Associates a Division of Cornell University Press. Ithaca and London.

Vincken, J.P., L. Heng, A. Groot and H. Gruppen. 2007. Saponins, classification and occurrence in the plant kingdom. Phytochemistry 68:275-297.

Waterborg, J.H. 2002. The lowry method for protein quantitation. In: The Protein Protocols Handbook. $2^{\text {nd }}$ ed. Humana Press
Inc., NJ. 7-10.

Wina, E., S. Muetzel, E. Hoffmann, H.P.S. Makkar and K. Becker. 2005. Saponin containing methanol extract of Sapindus rarak affect microbial fermentation, microbial activity and microbial community structure in vitro. Anim. Feed. Sci. Technol. 121: 159-174. 